\title{
FOOD CULTURE IN IBN BATTUTA'S TRAVELOGUE
}

\author{
Aysel YILMAZ \\ Anadolu University, Faculty of Tourism, \\ 26470 Eskisehir, Turkey, e-mail: aysely@anadolu.edu.tr \\ Sibel ÖNÇEL \\ Anadolu University, Faculty of Tourism, \\ 26470 Eskisehir, Turkey, e-mail: sguler@anadolu.edu.tr \\ Medet YOLAL ${ }^{*}$ \\ Anadolu University, Faculty of Tourism, \\ 26470 Eskisehir, Turkey, e-mail: myolal@anadolu.edu.tr
}

\begin{abstract}
Citation: Yilmaz, A., Önçel, S., \& Yolal, M. (2018). FOOD CULTURE IN IBN BATTUTA'S TRAVELOGUE. GeoJournal of Tourism and Geosites, 22(2), 470-479. https://doi.org/10.30892/gtg.22216-303
\end{abstract}

\begin{abstract}
Travelogues are valuable information sources about the period they were written. Ibn Battuta of Tangiers, Morocco, is a famous traveler of the $14^{\text {th }}$ century. In his travelogue, Ibn Battuta exhibits a rich variety of information on the people, social life, beliefs and traditions of the period in the lands he travelled. The purpose of this study was to make an account of food culture in the medieval ages on the basis of Ibn Battuta's travelogue. The reason for choosing Ibn Battuta's travelogue as the basis of this study was his extensive travels starting from Africa to Middle East, Asia Minor, Europe and Asia in the 14th century. For the purpose of the study, a content analysis was conducted to determine the words about food, beverages, kitchenware used for cooking, ingredients of recipes, names of the dishes, cooking types, serving and materials for keeping food, jobs related to cooking, and places of eating mentioned in Ibn Battuta's travelogue. The lexicon was grouped on the basis of themes. A total of 13 themes were identified which were labeled as grains, flour and baked products, legumes, meat, seafood, milk and dairy products, aromatic herbs, spices and sweeteners, oily fruits and oils, fruits and vegetables, desserts, beverages, kitchenware and others. Findings revealed that factors such as geographical features, peoples' habits, economic conditions and religion influenced the food culture greatly. Conclusions were drawn on the basis of findings.
\end{abstract}

Key words: Ibn Battuta, travelogue, food culture

\section{INTRODUCTION}

Food culture of a society is initially determined by the natural resources of the society (Tez, 2015, p. 9). Therefore, food culture is a phenomenon that changes by the geography, time and the people. People's food culture is also associated with their lifestyle

\footnotetext{
* Corresponding author
} 
and culture. In this regard, food is a cultural product which has individual and social aspects (Çetin, 2006, p. 107). Akarçay (2016) explains that the relation between the food culture and sociology, history and anthropology has ties to social, economic and political structures of the societies. For example in Europe, food culture has been initially studied by ethnology, anthropology and sociology, but it has long been a neglected area in historical studies. Travelogues have been both interesting and popular throughout history (Stubseid, 1993), and they represent important resources to better comprehend beliefs, social life and food culture of the past. The purpose of travelogue authors is quite simply to give correct information about a geographical area. One of the prominent travelers of the medieval ages, Abu Abdullah Muhammed bin Abdullah bin Muhammed bin Ibrahim Levati Tanci or shortly Ibn Battuta, was born in Tangier in 1304. After making several travels around the old world, he returned to Morocco in 1354, occupied the position of qadi (muslim judge) and died in his native land in 1368 (Barsoum, 2006). Thanks to his travel writings, he was accepted to be one of the most famous travelers of the Medieval Period. In his travels, Ibn Battuta was first a pilgrim who went on the hajj to Mecca. Then he was a Sufi devotee, and was also a cultured adventurer -part of an elite community of cosmopolitan, literate and mobile gentlemen, who looked for hospitality and sought employment (Dunn, 1986, p. 11). He married in many countries he visited and actively participated in the social life. Ibn Battuta covered approximately 73,000 miles. In his travelogue, he made a detailed description of the societies he had visited, and he mainly focused on human beings (Aykut, 2015). His writings have also attracted the scholars in search of historical, anthropological and geographical facts of the period. However, his vivid, enthralling, immensely detailed descriptions of the era have not been studied in detail, especially in terms of food culture in the lands he had visited.

Therefore, the purpose of this study is to make an account of food culture: food and beverages, ingredients of recipes and kitchenware used for cooking and serving in the Middle Ages on the basis of Ibn Battuta's travelogue. Ibn Battuta travelled throughout Africa, Asia and Europe and provided an extensive account of food culture of the time in his extensive travelogue. Content analysis was employed for the purpose of the study. Consequently, the food culture of the regions and countries of the $14^{\text {th }}$ century was examined on the basis of Ibn Battuta's travels. Thus, the study is expected to contribute to the existing literature on the food culture of the past.

\section{LITERATURE REVIEW}

Travelogues are important historical documents as they reveal what the travelers experienced, saw and lived in the course of their travels to exotic and less-known places. However, they are also subject to criticism due to some of their exaggerated or contradictory information compared to historical facts, and found to be highly subjective (Koçyiğit, 2009; Saylan, 2014). One of the prominent travelers of the Middle Ages was Ibn Battuta, and his travelogue offers a reliable source due to its extensive and detailed account of the countries and places he visited. Ibn Battuta's travels covered a vast geography throughout Asia, Europe and Africa. His writings on these travels provided valuable information about these lands, and this travelogue has been translated and published in many languages (Dunn, 2012; Mackintosh-Smith, 2002; Abercrombie, 1991; Yerasimos, 1982; Meillassoux, 1972; Husain, 1936; Favret-Saada, 1969; Gabrieli, 1961; Gibb, 1929). When studies on Ibn Battuta's travels are examined, it is seen that these studies have focused on a specific place. For example, Koçyiğit (2009) examined Ibn Battuta's travels to Black Sea region of Asia Minor and Crimea. The author concludes that Ibn Battuta not only became acquainted with local administrators and notable individuals but also, he examined the geographical characteristics, social structures, economic and cultural 
characteristics of the lands he had visited. It is also seen that some scholars have examined the food culture in Ibn Battuta's travelogue. For example, Birol (1991) notes that Ibn Battuta appraised the food culture of Kipchaks, Chagatai Khanate and Khanate of the Golden Horde. Similarly, Varlık (2010) writes on what Ibn Battuta ate and drank during his travels in Anatolia. Varlik concludes that Ibn Battuta provided little information on the food culture of the peoples living in Anatolia.

Food culture of the Middle Ages has been an important topic for some researchers. For example, Varlık (2012a, 2012b) studies Istanbul and Anatolian cuisine written in the writings of three travelers at the end of the $14^{\text {th }}$ century (2012b). Similarly, Yerasimos (2011) studies food culture depicted in Evliya Çelebi's (Turkish explorer and traveler lived in the $17^{\text {th }}$ century) travelogue, and determines a gastronomical lexicon of 2,246 words. The author also offers information on the eating habits of Ottoman people. Çetin (2006) examines the food culture in Mamluk Sultanate. In a similar study, Çetin (2006) also studies the food culture in Mamluks on the basis of Turkish and Arabic resources.

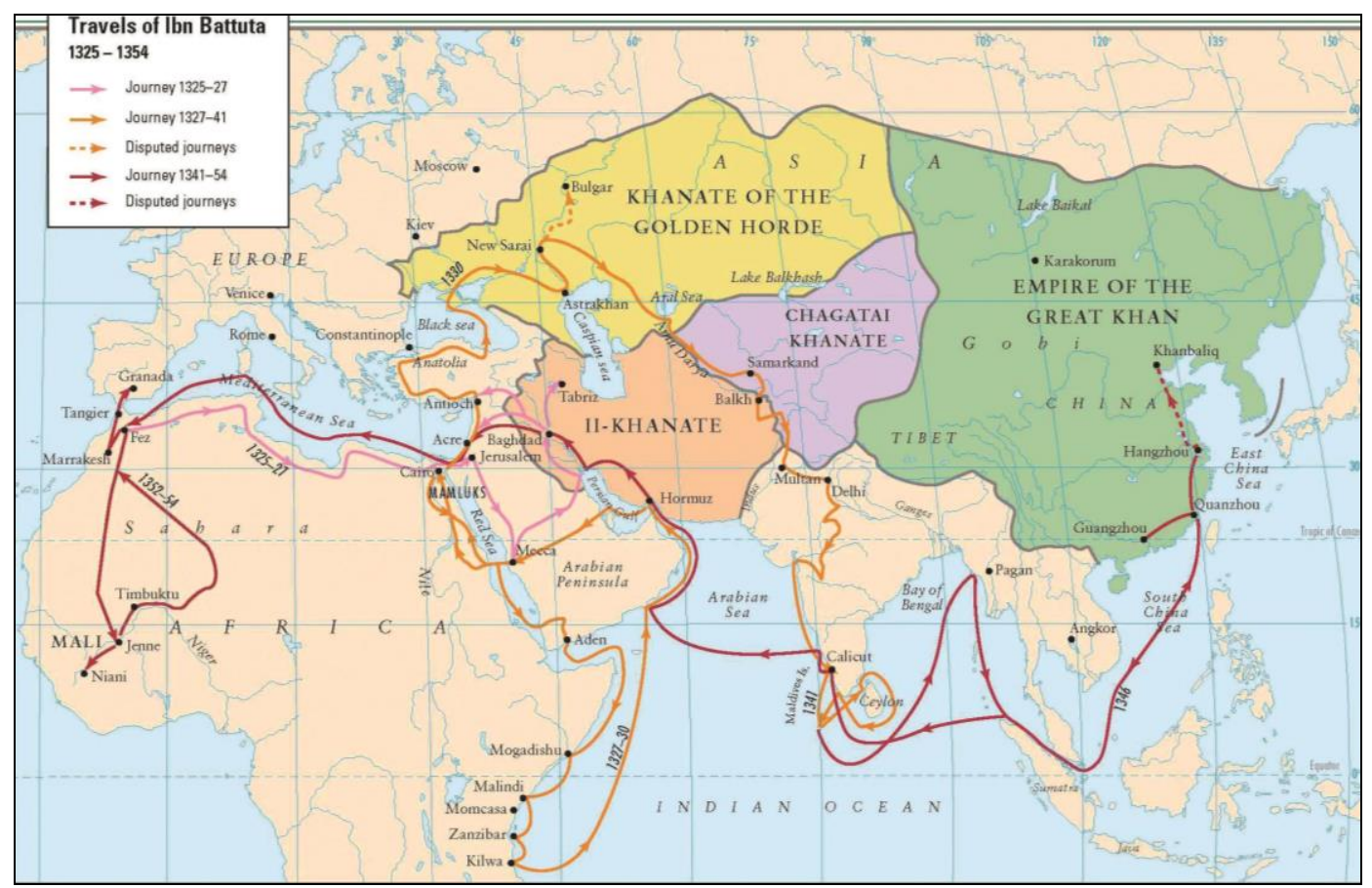

Figure 1. Travels of Ibn Battuta

(Source: http://tarihvemedeniyet.org/2010/o1/haritalarda-uc-ortacag-gezgini.html, 2018)

\section{METHODS}

Ibn Battuta is a Moroccan traveler who lived in the $14^{\text {th }}$ century. Ibn Battuta's travelogue was written after his return to Morocco in 1349 by Muhammed ibn Cuzey elKelbi. Some parts of Ibn Battuta's notes during his travels were lost in a robbery in the city of Kul, India, and some were gone when the ship he boarded in Calcutta (currently Kolkata) port in India sunk. Therefore, he penned his travels to this region on what he remembers (Birol, 1991). Ibn Battuta is accepted to be the most prominent traveler of his age due to his visits to the most important cultural centers of the era split around three continents (Africa, Asia and Europe). Human beings were in the focal point of his writings. Accordingly, he supplied valuable and abundant information on food culture 
while making an account of people's social lives, traditions, beliefs and customs. Therefore, Ibn Battuta's travelogue was chosen for examining the food culture of his age. Turkish translation of the travels (Ibn Battuta, 2015) was used in the study and paging of the quotations was based on this publication. Content analysis was employed in the study. According to Cohen, Manion and Morrison (2007), content analysis is defined as the specification and the summary of fundamental contents and their implied messages in written documents. Content analysis can also be described as deductive reading of a text (Bilgin, 2014, p. 1). Content analysis aims to reveal explanations for the data and interrelationships among them. Yıldırım and Şimşek (2006) note that the data is conceptualized and the concepts are reorganized in a rational way. Further, the themes that can explain the data are determined. Content analysis require the researchers to process the qualitative data, code the data, determine the themes, organize the codes on the basis of themes, designate and interpret the findings (Ylldırım \& Şimşek, 2006). For the purpose of this study, Ibn Battuta's travelogue was read in detail, and the words used for food, cooking and kitchenware were determined.

Therefore, the words on food culture in the travelogue was detected and coded. Coding denotes a process on the meaning of the message (Bilgin, 2014). In order to ensure the reliability of coding, strategies suggested by Creswell (2013, p. 250-253) were adopted in the study. In this regard, the analysis of the data was made by the contribution of two experienced researchers in the field of qualitative research. Data, which was coded by the researchers, was grouped under certain themes by the experts. Then their results were crosschecked with the results of the researchers. The discrepancies between two groups were solved, and where necessary, researchers used the codes provided by the experts.

\section{RESULTS}

A total of 13 themes were identified which were labeled as 'grains', 'flour and baked products', 'legumes', 'meat', 'seafood', 'milk and dairy products', 'aromatic herbs, spices and sweeteners', 'oily fruits and oils', 'fruits and vegetables', 'desserts', 'beverages', 'kitchenware' and 'others'.

\section{Grains}

The theme 'grains' in the travelogue included wheat, barley, millet, products and materials of wheat, vetch, oat and similar grains. While talking about the Barberi tribes on the banks of the Nile, Ibn Battuta noted that women of Berdame were tall and beautiful, and claimed that their food was 'well-grained millet and cow milk' (Ibn Battuta, 2015, p. 682). In the travelogue, a wide range of information on the grains was provided. For example, writing on the Turks: "Turkish people do not eat bread or stiff food; they cook a dish called 'dûki' (bulgur) which is like our 'anli'. First, they place the water pot on fire. When the water is boilt, they put some duki in it. If they have meat, they chop and add into pot and cook together. When the meal is cooked, they serve everyone's share in separate dishes." (Ibn Battuta, 2015, p. 313). "When we arrived in a village in Africa, black women immediately brought food that were made of millet called anli, milk, chicken, cedar flour, rice, 'funi' and broad bean powder (lubya). Funi looks like mustard seed and it is used to make couscous and 'aside' (flour soup). Travelers buy whichever they like." (Ibn Battuta, 2015, p. 666). Besides, Battuta noted that a community living on the coasts of Indian Ocean were harvesting a kind of wheat called 'ales', but claimed that in fact it was a kind of barley (Ibn Battuta, 2015, p. 251). Further, he noted that Sultanate of Kastamunya (currently Kastamonu, in Turkey) hosted him and sent him oats, and he was granted wheat and barley harvest from a town which was half day away from Kastamunya (Ibn Battuta, 2015, p. 305). He also noted that Indian people lived on grains like ' $k u d r u$ ' (a kind of millet), kal, mût/mot and mung (Ibn Battuta, 2015, p. 392). 


\section{Flour and Baked Products}

The theme 'flour and baked products' in the travelogue included flour, bread and baked products. Ibn Battuta wrote about the dishes served in the tables of ordinary people while traveling around India: rikak (thin bread), kebab and sweet stuffed cakes (Ibn Battuta, 2015, p. 434). On the banquets open to public, Ibn Battuta noted: "In India and in the land of Kipchaks, there is the custom of placing small, craddle-like tables in front of sharifs [an adjective meaning noble or highborn], scribes, sheikhs and qadis. ... On the tables, they serve dry thinbread, roasted lamb heads, and four oily breads stuffed with a kind of sweetener. And the bread is covered with a layer of thick halvah!" (Ibn Battuta, 2015, p. 508). Bread is the most frequently mentioned baked product in the travelogue. According to his writings: In Egypt, bread and soup were served to the visitors of Melik Mansur's tomb (Ibn Battuta, 2015, p. 47); bread, cheese, olive, vinegar and capers were served to the visitors of Deir-i Farus Monastery in Latakia, Syria (Ibn Battuta, 2015, p. 92); there were dealers selling bread under trees on the way to Basra (Ibn Battuta, 2015, p. 188); people were giving bread as gifts (Ibn Battuta, 2015, p. 189); in Kuhuristan, dervishes offered the bread in their zawiya [an Islamic religious school or monastery] that they collected walking from house to house (Ibn Battuta, 2015, p. 168); Ibn Battuta was welcomed with bread, water and dates in Ayzab in the vicinity of Jeddah (Ibn Battuta, 2015, p. 272); bread is baked once a week in Anatolia (Ibn Battuta, 2015, p. 273), each artisan carried bread in their bags in Denizli (Ibn Battuta, 2015, p. 281), cheap bread could be found in Kastamonu (Ibn Battuta, 2015, p. 304) and visiting dervishes were offered a table of bread, meat, rice and halvah at the zawiya of Fahreddin Bek (Ibn Battuta, 2015, p. 306). Battuta was offered bread in almost all places he visited (Istanbul, Khwarazm, India, Baghdad, Egypt, Iraq etc.)

\section{Legumes}

Regarding the theme of 'legumes', it was seen that this theme consisted of legumes and the dishes made of legumes. According to Ibn Battuta, rice was abundant and therefore cheap in Bengal. Moreover it was noted that rice was the only diet of Hinavr people in Afghanistan (Ibn Battuta, 2015, p. 539). Regarding India, Battuta wrote about mung (a kind of small round green bean) dish: "Mung is a kind of bean. But the grains are longer, and it is lime green. Mung is cooked with rice and oil. They call this dish as kusheri. They use to consume kusheri in the mornings." (Ibn Battuta, 2015, p. 392).

Ibn Battuta mentioned the existence of chickpeas in India (Ibn Battuta, 2015, p. 392), in Delhi by the bankd of Ganges River (Ibn Battuta, 2015, p. 473) and China (Ibn Battuta, 2015, p. 612), and lentil and gram in Egypt (Ibn Battuta, 2015, p. 643).

\section{Meat}

This theme consisted of types of meat such as beef, lamb, poultry meat, meat products and meat storage methods. Ibn Battuta wrote that during his voyage to Crimea, governor of Azak (today's Azov) was very hospitable to him, and offered him dishes made of horse meat and other meat (Ibn Battuta, 2015, p. 315). According to Battuta, Uzbek Turks frequently consumed mare meat and lamb (Ibn Battuta, 2015, p. 313), Sicilmâsâ people (in Africa) ate camel meat (Ibn Battuta, 2015, p. 660), non-Muslims in China consumed pork and dog meat (Ibn Battuta, 2015, p. 613), Byzantine people eat pork (Ibn Battuta, 2015, p. 332) and Kipchaks preferred beef (Ibn Battuta, 2015, p. 331). Moreover, Ibn Battuta noted that chicken and roosters of China were massive, even bigger than the geese of Morocco: "We bought a chicken, and when we wanted to cook it we noticed that the pot is small for the meat. Therefore we divided the chicken into two pots. The roosters of that place were like ostriches... I had seen such a rooster in Kavlem (in India) and was surprised, and I thought it to be an ostrich!" (Ibn Battuta, 2015, p. 613). In India, he tasted a meal called semusek which is cooked with almonds, walnuts, onions and spices (Ibn Battuta, 2015, p. 388). During his tour in Anatolia, Ibn Battuta arrived in Sinop, and he ate rabbit meat, 
which is forbidden in Shia branch of Islam, in order to prove that he is a member of Maliki branch, rather than being a Shiite (Ibn Battuta, 2015, p. 308). Furthermore, it is understood that Battuta had tried salt-cured meat and dried meat in Saraycik on his way to Khwarazm (Ibn Battuta, 2015, p. 344) and Maldives (Ibn Battuta, 2015, p. 565).

\section{Seafood}

Three groups were determined under the theme of 'seafood': fish, fish products and fish storage methods. For example, Ibn Battuta mentioned a strange fish that he saw in Maldive islands. The fish, which resembled lamb, was the primary food for the locals and was named as kulbulmas. Kulbulmas was preserved by drying, and was exported to India, China and the Yemen. The author claimed that the fish had been rumoured to have aphrodisiac properties (Ibn Battuta, 2015, p. 556). Moreover, the author wrote that he was served salted sardine in Kavlem, and noted that he had not eaten the uncooked fish (Ibn Battuta, 2015, p. 570). Ibn Battuta repeatedly mentioned fish in his visits to the lands by the sea such as Wasit city in Iraq (Ibn Battuta, 2015, p. 182), Basra (Ibn Battuta, 2015, p. 188), and Sri Lanka (Ibn Battuta, 2015, p. 579).

\section{Milk and Dairy Products}

Under the theme of 'milk and dairy products', two groups were specified: milk of camel, mare, cow, sheep and Anatolian buffalo, and dairy products such as koumiss, yoghurt and cheese. In Crimea for example, after the dinner, Turks drunk a beverage called koumiss which was made of mare milk. Additionally, it was understood that they put yoghurt on a dish called borani, and poured milk in the soup made of homemade pasta (Ibn Battuta, 2015, p. 313). On the way to Jeddah, Battuta noted that an Arab child was fed by merely camel milk (Ibn Battuta, 2015, p. 272), and the meals were just the camel milk in Aydhab [a lost port city of the Red Sea] (p. 6o). Ibn Battuta talked about the abundance of the milk of Anatolian buffalo in Damietta [a port city in Egypt] (Ibn Battuta, 2015, p. 41) and Cenani [a province in India] (Ibn Battuta, 2015, p. 381), koumiss, cow and sheep milk in Constantinople (Ibn Battuta, 2015, p. 331). Traditionally, people eat curd or yoghurt in Hinavr of Afghanistan: "When these are served, it means that nothing more will be served.” (Ibn Battuta, 2015, p. 539).

\section{Aromatic Herbs, Spices and Sweeteners}

The theme of 'aromatic herbs, spices and sweeteners' included the groups of spices, salt, musk mallow, vegetation, aromatic herbs and flower juices. In the travelogue, frequently mentioned spices were clove, the kakula, kumarî, saffron, sweet basil, ginger, black pepper, cinnamon, mustard, green ginger and cemun. Salt was found in the form of rock salt and andarani salt. Vegetation used for gastronomic purposes were listed as follows: vegetables, herbs, couch grass, almond branches, camphor, sesame seed, hemp, cannabis, sugar cane, banana leaves and mung leaves. Aromatic herbs were as follows: anise, rose, essence herbs, cinnamon, orange flower, incense and carnation flower.

Ibn Battuta noted that he was hosted by sultan Aydınoglu Muhammed [sultan of state founded in the Aegean coasts of Anatolia], and the sultan ordered his men to punish the treasurer after seeing that no spices or vegetables were used while cooking the dinner (Ibn Battuta, 2015, p. 290). In his travels to Indian lands, spices were more frequently mentioned. Battuta wrote that he was served meat cooked with oil, onion and green ginger in chinaware (Ibn Battuta, 2015, p. 388). While writing about Ceylon, he noted that the city was full of cinnamon logs (Ibn Battuta, 2015, p. 577). Moreover, he noted that most of the trees in Java were coconut, Areca palm, cloves, oudh tree, apple tree, orange tree and kapur tree (Ibn Battuta, 2015, p.602).

\section{Oily Fruits and Oil}

This theme was composed of the groups of nuts and oils. Nuts mentioned in the travelogue were Buva nut, coconut, walnut, hazelnut, peanut, almond and nargil (a kind 
of nut specific to India). Oils were found as olive oil, suet, fat, sesame oil, butter and bile oil. According to Ibn Battuta, most of the trees in Shiraz and Anatolia in which Turks mostly lived (Ibn Battuta, 2015, p. 200) were nuts. He was surprised to see a specific tree in the Yemen and described it as: "This tree called Nargil is in fact a kind of nut tree specific to India. ... At first sight you think it to be date tree or palm tree, but it bears walnut.” (Ibn Battuta, 2015, p. 255). Regarding the oils, Battuta noted that Nablus [a city in the northern West Bank north to Jerusalem] and Damascus were rich in olives, and olive oil was exported to other countries (Ibn Battuta, 2015, p. 69). In Egypt, for example there was no solid fat, and sesame oil, butter and olive oil were used for cooking (Ibn Battuta, 2015, p. 643). Ibn Battuta noted that there were no solid fat or olive oil in a town called Buda in Algeria, and that they imported these oils (Ibn Battuta, 2015, p. 686).

\section{Fruits and Vegetables}

This theme included a variety of groups such as vegetables, fruits, bananas and grapes. The vegetables mentioned in the travelogue were broad bean, almond, artichoke, pepper, radish, Indian cane, pumpkin, zucchini, purslane and onion. The fruits expressed in the book were raspberry, plum, mango, pear, quince, apricot, melon, watermelon, orange, apple, blackberry, mulberry, fig, date, lemon, pomegranate, citrus, peach, cherry, and some local fruits such as cammun (eugenia jambolana), Luban-i Java, tendu and mehva. In the travelogue, it is noted that Khwarazm melon, grapes and some other fruits were dried. Similarly, different kinds of bananas and grapes were mentioned.

Ibn Battuta talked about several fruits and fruit sellers in his travels to different lands. For example he liked Bukhara and Khwarazm melons the best (Ibn Battuta, 2015, p. 348). Similarly, he relished green ginger, pepper, lemon, banana and mango in Java Island (Ibn Battuta, 2015, p. 390, 602), grapes, plums, apples and quinces in Byzantine land (Ibn Battuta, 2015, p. 333), grapes, cammun, lemon and coconuts in Maldives (Ibn Battuta, 2015, p. 556), and dates and banana in Qalhat, Oman (Ibn Battuta, 2015, p. 261).

\section{Desserts}

This theme consisted of confectionery courses and honey. The desserts mentioned in the travelogue consisted of ashura, halvah, carob sweets, fruit paste, batter, and some local desserts such as mukarrada, sabuniye, celd-i feres etc. Moreover, the travelogue mentioned honey and coconut honey. When he was in Baghdad, Ibn Battuta wrote that eleven pots of halvah was prepared and offered to Sultan. He also mentioned desserts specific to this region: "Majesty! There are various kinds of desserts... 'For example this dessert is called mukarrada [a kind of halvah]' .... 'And this is lukaymatulkadi [some sort of donut]'.” (Ibn Battuta, 2015, p. 504-505). Similarly, in India, Battuta was offered some local desserts called sabuniye. He noted that all the desserts were covered with hişti, a crust made of flour, sugar and oil (Ibn Battuta, 2015, p. 388).

\section{Beverages}

The theme of 'beverages' included beverages such as tea, sorbet, spirits, wines, fruit juices, boza (traditional cereal-based fermented cold drink with a slightly acidic sweet flavor) and grape juice. It was understood that fuka (a beverage made of barley) was popular in Baghdad (Ibn Battuta, 2015, p. 505). Similarly, koumiss was popular in Uzbekistan (Ibn Battuta, 2015, p. 321). It was noted that there were large leather bottles full of rose sherbet in Kanbay region in India (Ibn Battuta, 2015, p. 156), and everyone drunk from these bottles. This sherbet was also served in funerals (Ibn Battuta, 2015, p. 490). It was written that date, barley, grapes and similar fruits were pressed in cruses in Siberia, and their juices were consumed (Ibn Battuta, 2015, p. 328). People drunk Zamzam holy water in Mecca (Ibn Battuta, 2015, p. 135). In Maldiv Islands, people produced a kind of sherbet made of coconut milk and butter (Ibn Battuta, 2015, p. 556). In this vein, Ibn Battuta wrote: "I asked what people were drinking? He replied: 'It is the 
juice of boiled wheat.' I could not continue drinking when I felt tartness. Dukî is a kind of liquor. Such a drink is called as boza by the locals." (Ibn Battuta, 2015, p. 314).

\section{Kitchenware}

The theme of 'kitchenware' consisted of groups of pots, plates, goblets, spoons, scoops and ladles, containers, beverage servers, bowls, table kits, table clothes, knives, food protection equipment, and cooking equipment. In this regard, it was seen that Ibn Battuta was served with golden and silver kitchenware. Golden and silver pots were mentioned in the travelogue. Similarly, plates and spoons were also made of gold, silver and copper, and the meals were served or delivered with copper ladles. The goblets were noted to be gold or glassware. Cooking equipment was composed of pots, saucepans, oven, barbecue, fireplace and martaban (big pans). Containers were found to be gold, copper, iron, silver, clay, chinaware. Beverages were served in glasses, carafes, tankards and pannikins, and earthenware pots and jars. Bowls were mentioned to be glass, china and earthen. Food was eaten on large salvers on the ground used as tables and they were mostly made of copper. Further, table clothes were also used under these salvers. Several kinds of small or big knives were also mentioned in the book. Finally, food was protected and saved in leather bottles, barrels and earthenware jars. Ibn Battuta mentioned golden or silver pots full of sherbet; golden or silver spoons; chinaware pots full of sherbet; and wooden spoons on his travels in Asia Minor, and his visit to sultan. He noted that "Those who do not use gold because of their religious beliefs use china bowls and wooden spoons." (Ibn Battuta, 2015, p. 291). In his travel to Khwarazm, in a house he was hosted, he observed that there were several arches in the house and people traditionally hung gold or silver plated bowls and pots under these arches (Ibn Battuta, 2015, p. 345). Ibn Battuta talked about golden tableware in the house of Kutlu Dumur, the governor of Khwarazm. Similarly, he was hosted in tables fully composed of golden or silver tableware in Dihli land, in India (Ibn Battuta, 2015, p. 487). He noted that beautiful pots and bowls decorated with gold were produced in Malaga, today's Spain (Ibn Battuta, 2015, p. 656). Copper salvers, pots, plates and ladles were used in the tables of Honavar sultan (Ibn Battuta, 2015, p. 539). Finally, he noted that copper tableware was a must in the dowries of young girls in Damascus (Ibn Battuta, 2015, p. 71).

\section{Others}

The theme 'others' includes groups of gastronomical professions, gardens, trees, aphrodisiac, narcotics, dried food, cannibalism, leaves, places and recipes. Ibn Battuta mentioned professions regarding cooking. For example, he mentioned that meat-smashers called baruci in Siberia (Ibn Battuta, 2015, p. 327), cooks, bakers, turnspits (kebab grilling), sweet makers, fruit juice and sherbet servers, toothpick holders (toothpick were made of a pepper tree specific to India) (Ibn Battuta, 2015, p. 447), fishermen (Ibn Battuta, 2015, p. 626), earthenware potters (Ibn Battuta, 2015, p. 612) and guest greeters (Ibn Battuta, 2015, p. 396). Since Ibn Battuta's travels covered a vast geography, he came across a variety of trees, orchards and gardens. These trees were sandalwood, pepper tree, aloes, tamarisks, walnuts, palm trees, date-trees, chestnut tree, banana trees, teasels, sweetgum trees, citrus trees, gale trees, valonia oaks, sandalwoods and cedar woods. These trees were mentioned to be in gardens and orchards. Ibn Battuta noted that there were eleven large scale sugar distillation shops on the banks of the Nile in a town called Menlevi (Ibn Battuta, 2015, p. 57). He mentioned bazaars where one could find greengrocers, cooks and bread-makers, and a bazaar of fruits in Najaf (in Iraq) (Ibn Battuta, 2015, p. 175). He also mentioned mills in Horasan (in Erzurum, Turkey) (Ibn Battuta, 2015, p. 372), soup kitchen and eating houses in Bikaner (Ibn Battuta, 2015, p. 543). Meanwhile, Battuta mentioned wild black people living on the banks of the Nile who ate a maid, and painted their faces with the blood of the maid (Ibn Battuta, 2015, p. 678). Finally, Ibn Battuta noted that coconut had aphrodisiac properties (Ibn Battuta, 2015, p. 255, 556). 


\section{CONCLUSION AND DISCUSSION}

The primary purpose of this study was to investigate food culture in the Middle Ages on the basis of Ibn Battuta's travelogue. Travelogues shed light on the social, economic and cultural characteristics of the geographies of the past. Further, they act as the interpreters of the period in which the travelogue was written.

Specifically, this study contributes to the existing literature on gastronomy and food culture of our ancestors in that it uses the writings of a well-known traveler of the medieval ages, namely Ibn Battuta. Ibn Battuta was not merely a traveler as Barsoum (2006) observed. He also sought out knowledge and vividly narrated what he had seen and experienced. He made a well-structured account of the geography, people and their culture in a vast land. Although there are certain travelers that consider food as a primary motivation for their trip (Lopez-Guzman et al., 2018), Ibn Battuta traveled for other reasons but he provided valuable information on the food culture of the people he had visited. As such, Ibn Battuta offered a valuable source for understanding the food culture, cooking and storage methods, recipes, ingredients and the materials used for cooking. Consequently, he contributed to our understanding on social, economic and cultural facts of the era.

Findings of the study provided a total of 13 themes which were labeled as grains, flour and baked products, legumes, meat, seafood, milk and dairy products, aromatic herbs, spices and sweeteners, oily fruits and oils, fruits and vegetables, desserts, beverages, kitchenware and others. Even the list of these themes suggested a significant number of food lexicon was provided in Ibn Battuta's writings. This can be justified by Ibn Battuta's travels in a vast geography covering Africa, Asia and Asia-Pacific. Further, the findings suggest that factors such as geographical conditions, climate, economical status and religious practices have an important influence on the food culture in different regions.

It is understood that geography is the most influential factor determining the food culture in a certain area. Vegetation, livestock, cooking and storage methods are determined by the geography. For example, people prefer dry food in sunny and warm areas. Similarly, people living in coastal areas mostly consume seafood while people in hinterland use to prefer livestock such as lamb, veal, camel or buffalo meat. In short, it is seen that people consume mostly the food that they could find in their vicinity. Findings of the study reveal that some food is prohibited in certain areas because of the religious restrictions. In this regard, Battuta mentioned pork meat which was not eaten by Muslims, and rabbit meat which is prohibited in Shia branch of Islam. As such, it is important to understand religious practices of the people while cooking or serving food for the foreigners. Findings also suggest that economic status of the people determined the tools and materials used in cooking and serving food. Wealthier people, administrators and nobles used golden or silver kitchenware while serving their guests to show off their status and wealth. Similarly, they employed servants and cooks for cooking and serving while others cook for themselves. Further, the diversity of the menu and the ingredients of the recipe vary significantly on the tables of these people. Findings on the food culture of the $14^{\text {th }}$ century provide a valuable resource for the researchers, academicians and gastronomy students. As such, people may have the chance to evaluate the evolution of the food culture in the course of centuries in different regions. In this vein, the results of the study may also be used by the practitioners to revive old, forgotten gastronomical values and recipes. Moreover, the information provided by this study can be used for those who want to diversify their menus and tastes. Accordingly, a connection between past and present can be made to develop recipes that can fit contemporary tastes and preferences. The results of this study should be evaluated in the light of certain limitations. The primary limitation of this study is that only the food culture in the travelogue of Ibn Battuta was examined. Therefore, future studies are needed to examine the writings of other travelers of the same 
or other periods. As such, future studies have the potential to broaden our knowledge and understanding of the food culture of the past and its evolution in the course of time.

\section{REFERENCES}

Abercrombie, T.J. (1991). Ibn Battuta: Prince of travelers. National Geographic.

Akarçay, E. (2016). Gastronominin toplumsal serüveni: Sosyoloji (Social adventure of gastronomy), in H. Yllmaz (ed.), Gastronomi ve medya (Gastronomy and media), pp. 212-237, Anadolu Üniversitesi Yayınlan, Eskișehir.

Aykut, A.S. (2015). Tancall Ibn Battuta ve seyahatnamesine dair (On the travelogue of Ibn Battuta of Tanci), in Ibn Battuta seyahatnamesi (Travels of Ibn Battuta), translated by A. Sait Aykut, 4th Edition, Yap1 Kredi Yayınları, İstanbul.

Bilgin, N. (2014). Sosyal bilimlerde içerik analizi teknikler ve örnek çahş̧malar (Content analysis tecnics and cases in social sciences), 3rd Edition, Siyasal Kitabevi, Ankara.

Birol, N. (1991). Ibn Battuta çağında Deşt-i Kipçak ve Türkistan (Cumania and Turkistan in the age of Ibn Battuta), Unpuplished Masters Thesis, Ankara University, School of Social Sciences, Ankara.

Barsoum, M. (2006). The traveller and his scribe: In the footsteps of Ibn Battuta and their rendering by Ibn Juzayy, in The Journal of North African Studies, vol 11, no. 2, p. 193-203.

Cohen, L., Manion, L., \& Morrison, K. (2007). Research methods in education, 6. Edition, Routledge, London.

Creswell, J. W. (2013). Qualitative inquiry and research design: Choosing among five approaches, 3rd Edition. USA: Sage Publications.

Çetin, A. (2006). Memluk Devletinde Yemek Kültürüne Genel Bir Bakış (An overview of food culture in Memluks), in Millî Folklor, vol 18, no. 72, p. 107-117.

Dunn, E.R. (2012). The adventures of Ibn Battuta: A Muslim traveler of the fourteenth century, University of California Press, California.

Favret-Saada, J. (1969). Voyages d'Ibn Battuta, in L'Homme, vol. 9, no. 4, p. 120-121.

Gabrieli, F. (1961). I Viaggi di Ibn Battutah, Sansoni, Firenze.

Gibb, H.A.R. (1929). Selection from Ibn Battuta, Broadway House, London.

Husain, A.M. (1936). La Gouvernement du Saltanat de Delhi: Etude critique d'Ibn Battuta, Maisonneuve, Paris.

Koçyiğit, T. (2009). Ibn Battuta'nın Karadeniz seyahati üzerine bazı mülahazalar (Thoughts on Ibn Battuta's travels to Black Sea region), in Dinbilimleri Akademik Araştırma Dergisi, vol. 9, no. 4, p. 53-73.

Lopez-Guzman, T., Torres Naranjo, M., Perez-Galvez, J.C., \& Carvache Franco, W. (2018). Gastronomic perception and motivation of a touristic destination: The City of Quito, Ecuador. GeoJournal of Tourism and Geosites, vol. 21, no. 1, p. 61-73.

Mackintosh-Smith, T. (2002). Travels with a Tangerine: A journey in the footnotes of Ibn Battuta, Ibn Battuta, Mac Millan Publishers Ltd., London.

Meillassoux, C. (1972). L'itineraire d'Ibn Battuta de Walata a Malli, in The Journal of African History, vol. 13, no. 3, p. 389-395.

Saylan, K. (2014). Gümüşhane idari, sosyal ve ekonomik tarih (1850-1918) (Administarive, social and economic history of Gumushane 1850-1918), Gümüşhane Üniversitesi Yayınları, Istanbul.

Stubseid, A. S. K. (1993). Travelogues as indices of the past, in The Journal of Popular Culture, vol. 26, no. 4, p. 89-100.

Tez, Z. (2015). Lezzetin tarihi - geçmişten bugüne yiyecek, içecek ve keyif vericiler (The history of taste - high spirits, food and drinks from past to present), 3rd Edition, Hayykiyap, İstanbul.

Varlı, M.B. (2010). Ibn Battûta Anadolu yollarmda neler yedi? (What did Ibn Battuta eat on the roads of Anatolia?), in Kebikeç Dergisi, no 29, p. 147-152.

Varlık, M. B. (2012a). Üç seyyahın kaleminden İstanbul ve Anadolu mutfağı üzerine notlar (Notes of three travellers on Istanbul and Anatolian cuisine), in Yemek ve Kültür, no. 33, p. 128-197.

Varlık, M.B. (2012b). XVI. Yüzyll sonlarında dört seyyahın İstanbul'un beslenme kültürü üzerine notları Fresne-Canaye, Gerlach, Schweigger, Lubenau (Notes of four travellers on food culture of Istanbul Fresne-Canaye, Gerlach, Schweigger, Lubenau), in Yemek ve Kültür, no. 30, p. 12 - 28.

Yerasimos, M. (2011). Evliya Çelebi Seyahatnâmesinnde yemek kültürü - yorumlar ve sistematik dizin (Food culture in Evliya Çelebi's travelogue -critiques and systematic index), Kitap Yayınevi, İstanbul.

Yerasimos, S. (1982). Voyages de Battuta. Fm/La Découvert, Paris.

Yıldırım, A., \& Şimşek, H. (2006). Sosyal bilimlerde nitel araştırma yöntemleri (Qualitative research methods in social sciences), Seçkin Yayıncllı, Ankara.

*** Ibn Battuta, E.A.M (2015). Ibn Battuta seyahatnamesi (Travels of Ibn Battuta), translated by A. Sait Aykut, 4th Edition, Yapı Kredi Yayınları, İstanbul.

http://tarihvemedeniyet.org/2010/o1/haritalarda-uc-ortacag-gezgini.html, 16.03.2018.

Submitted:

30.03.2018
Revised:

11.06.2018
Accepted and published online 14.06.2018 